Vol 2, No. 2, Desember 2019, DOI: https://doi.org/10.34007/iehss.v2i2.104

\title{
Tinjauan terhadap Kualitas Kerja Karyawan Berdasarkan Pengalaman Kerja dan Motivasi pada PT. Latexindo Toba Perkasa Kabupaten Deli Serdang
}

\section{Review of Employee Work Quality Based on Work Experience and Motivation at PT. Latexindo Toba Perkasa Deli Serdang Regency}

\author{
Amrin Mulia Utama \\ Fakultas Ekonomi dan Bisnis, Universitas Medan Area, Indonesia
}

Diterima: November 2019; Disetujui: Desember 2019; Dipublish: Desember 2019

*Coresponding Email: amrinmuliautama@gmail.com

\begin{abstract}
Abstrak
Penelitian ini bertujuan untuk mengetahui pengaruh variabel pengalaman kerja dan motivasi terhadap kualitas kerja karyawan PT. Latexindo Toba Perkasa Kab Deli Serdang. Penelitian ini termasuk penelitian asosiatif. Jumlah sampel adalah sebanyak 55 karyawan. Teknik analisis data dalam penelitian ini adalah teknik analisis regresi linier berganda. Data penelitian bersumber dari data primer dan proses pengumpulan data menggunakan wawancara dan kuesioner. Dari hasil penelitian diperoleh bahwa variable pengalaman kerja berpengaruh positif signifikan terhadap kualitas kerja karyawan, dimana nilai t hitung 3,714 > nilai $t$ tabel 1,67469 dengan signifikansi $0,000<0,005$. Variable Motivasi memiliki pengaruh positif signifikan terhadap kualitas kerja karyawan dimana $t$ hitung adalah 3,511 $>\mathrm{t}$ tabel 1,67469 dengan signifikansi 0,001 $<0,005$. Pengalaman kerja dan Motivasasi secara simultan memengaruhi kualitas kerja karyawan, di mana $\mathrm{F}$ menghitung 38,575 dengan tingkat signifikansi 0,000 $<0,005$. Nilai F yang dihitung 38,575 dan F tabel 3,18. Nilai signifikansi adalah 0,001<0,005.
\end{abstract}

Kata Kunci: Pengalaman Kerja, Motivasi, Kualitas Kerja Karyawan

\begin{abstract}
This study aims to find out) The effect of work experience and motivation variables on employee performance of PT. Latexindo Toba Perkasa Deli Serdang District This research is categorized as associative research. Samples taken were 55 employees of PT. Latexindo Toba Perkasa Deli Serdang District. Data analysis techniques in this study are multiple linear regression analysis techniques. The research data comes from primary data and the process of collecting data using interviews and questionnaires. From the results of the study obtained Work experience has a significant positive effect on employee performance, where $t$ is equal to $3,714>t$ table 1.67469 with a significance of 0.000 $<0.005$. Motivation has a significant positive effect on employee performance where $t$ count is $3,511>t$ table 1.67469 with significance $0.001<0.005$. Work experience and motivation influence simultaneously on employee performance where $F$ count is 38,575 with a significance level of $0,000<0.005$. The calculated $F$ value is 38.575 and $F$ table 3.18. Significance value $0.001<0.005$
\end{abstract}

Keywords: Work Experience, Motivation, Work Quality of Employees

How to Cite: Utama, A.M. (2019). Tinjauan terhadap Kualitas Kerja Karyawan Berdasarkan Pengalaman Kerja dan Motivasi pada PT. Latexindo Toba Perkasa Kabupaten Deli Serdang. Journal of Education, Humaniora and Social Sciences (JEHSS). 2 (2): 279-291. 


\section{PENDAHULUAN}

Keberhasilan suatu organisasi sangat tergantung pada kualitas kerja organisasi yang baik dan buruk. Kualitas pekerjaan suatu organisasi tergantung pada kualitas pekerjaan karyawannya di mana setiap karyawan adalah motor untuk menjalankan suatu perusahaan. Pekerjaan yang berkualitas baik dari karyawan akan berdampak langsung pada kemajuan atau kemunduran yang perusahaan (Daud, et.al. 2019).

PT. Latexindo Toba

Perkasa Kabupaten

Deli

Serdang adalah sebuah pribadi perusahaan yang memproduksi latex dalam produksi sarung tangan lateks dengan jenis powdered. Dan powder free. latex untuk industry di Sumatera utara yang merata dan terus menerus dengan memperhatikan prinsip-prinsip perusahaan dalamn pengolahannya perusahaan tidak mengabaikan kondisi sosial, budaya dan masyarakat. Sebagai perusahaan yang memberikan layanan kepada masyarakat, perusahaan berupaya mengelola manajemen secara profesional untuk pencapaian tujuan perusahaan, salah satunya adalah meningkatkan kualitas kerja.

Adapun beberapa masalah pengalaman kerja di kantor PT. Latexindo Toba Perkasa Kabupaten Deli Serdang adalah kurangnya keahlian yang dimiliki oleh karyawan dan ada beberapa karyawan yang bekerja di perusahaan masih memiliki keterampilan dan pengetahuan yang terbatas dalam melakukan pekerjaan mereka. Sedangkan untuk motivasi kerja, masalahnya adalah kurangnya motivasi kerja dari karyawan yang mungkin akibat dari pemberian imbalan ekstrinsik kadang-kadang tidak diberikan tepat waktu. Untuk masalah kualitas kerja karyawan PT. Latexindo Toba Perkasa Kabupaten Deli Serdang adalah pekerjaan yang tidak selalu selesai tepat waktu, layanan tidak optimal dan masih banyak karyawan yang terlambat datang untuk bekerja.

\section{METODE PENELITIAN}

Jenis penelitian ini dapat diklasifikasikan sebagai penelitian asosiatif kausal. Lokasi Penelitian dilakukan di kantor PT. Latexindo Toba Perkasa Kab Deli Serdang Jl. Raya KM. 11 No. 55, Mulyorejo, Sunggal, Paya Geli, Sunggal, Kabupaten Deli Serdang, Sumatera Utara 20128 Telp.(061)8468856

Sampel dalam penelitian ini adalah karyawan PT. Latexindo Toba Perkasa, Kabupaten Deli Serdang, dengan total 64 karyawan. Pengambilan sampel 
menggunakan teknik slovin, yang merupakan sensus, di mana semua anggota populasi diambil sampelnya dan sampel yang digunakan adalah 55 orang

Teknik Analisis Data, Instrumen Uji, Uji validitas digunakan untuk mengukur validitas atau validitas kuesioner. Suatu kuesioner dikatakan valid jika pertanyaan pada kuesioner tersebut mampu mengungkapkan sesuatu yang akan diukur oleh kuesioner tersebut. Uji validitas dilakukan dengan membandingkan nilai dengan memberikan dukungan dalam mengungkapkan apa yang ingin Anda katakan dengan kriteria penguji berikut: $\quad$ 1) Jika (dengan sig 0, 05 ): maka instrumen tersebut vali; 2) Jika (dengan sig 0,05 ): maka instrumen tidak valid.

Uji reliabilitas, Keandalan uji inidiukur dengan uji statistik Cronbach Alpha. Konstruk atau variabel dikatakan dapat diandalkan jika memberikan nilai Cronbach Alpha> 0,70 (Nunnally, 1994 dalam Ghozali, 2016).

Metode analisis data yang digunakan dalam penelitian ini adalah analisis regresi berganda. Regresi linier berganda adalah metode statistik umum yang digunakan untuk menguji hubungan antara variabel dependen dengan beberapa variabel independen.

Pengujian Hipotesis, Koefisien Determinasi, menurut Ghozali (2012) koefisien determinasi adalah alat untuk mengukur sejauh mana kemampuan model dalam menjelaskan variasi variabel dependen. Koefisien determinasi adalah antara nol atau satu. Nilai yang kecil berarti kemampuan variabel independen untuk menjelaskan variasi variabel dependen sangat terbatas. Dan sebaliknya jika nilai mendekati 1 berarti bahwa variabel independen menyediakan hampir semua informasi yang diperlukan untuk memprediksi variabel dependen.

Uji Parsial (uji t), menurut Ghozali (2012) uji-t beda digunakan untuk menguji sejauh mana pengaruh variabel independen yang digunakan dalam penelitian ini secara individual dalam menjelaskan variabel dependen secara parsial.

Uji Simultan (Uji f). Menurut Ghozali (2012: 98) Uji Statistik F pada dasarnya menunjukkan apakah semua variabel independen atau variabel independen yang dimasukkan dalam model memiliki pengaruh bersama pada variabel dependen atau variabel dependen. 


\section{HASIL DAN PEMBAHASAN}

\section{Validitas dan Keandalan}

Pada tabel 4.1 berikut diperoleh hasil uji validitas dalam penelitian ini

Tabel 4.1

Hasil Uji Validitas

\begin{tabular}{|c|c|c|c|c|}
\hline Variabel & Pernyataan & $\mathrm{r}_{\text {menghitung }}$ & tabel $\mathbf{r}$ & Informasi \\
\hline \multirow{6}{*}{ Pengalaman Kerja $\left(\mathrm{X}_{1}\right)$} & $\mathrm{P}_{1}$ & 0,710 & 0,2656 & Valid \\
\hline & $\mathrm{P}_{2}$ & 0,545 & 0,2656 & Valid \\
\hline & $\mathrm{P}_{3}$ & 0,500 & 0,2656 & Valid \\
\hline & $\mathrm{P}_{4}$ & 0,578 & 0,2656 & Valid \\
\hline & $\mathrm{P}_{5}$ & 0,587 & 0,2656 & Valid \\
\hline & P6 & 0,614 & 0,2656 & Valid \\
\hline \multirow{8}{*}{ Motivasi $\left(\mathrm{X}_{2}\right)$} & $\mathrm{P}_{1}$ & 0,553 & 0,2656 & Valid \\
\hline & $\mathrm{P}_{2}$ & 0,818 & 0,2656 & Valid \\
\hline & $\mathrm{P}_{3}$ & 0,818 & 0,2656 & Valid \\
\hline & $\mathrm{P}_{4}$ & 0,599 & 0,2656 & Valid \\
\hline & $\mathrm{P}_{5}$ & 0,716 & 0,2656 & Valid \\
\hline & P6 & 0,538 & 0,2656 & Valid \\
\hline & $\mathrm{P}_{7}$ & 0,549 & 0,2656 & Valid \\
\hline & P8 & 0,716 & 0,2656 & Valid \\
\hline \multirow{8}{*}{$\begin{array}{l}\text { Kualitas } \\
\text { kerja karyawan (Y) }\end{array}$} & $\mathrm{Q}_{1}$ & 0,559 & 0,2656 & Valid \\
\hline & $\mathrm{P}_{2}$ & 0,709 & 0,2656 & Valid \\
\hline & $\mathrm{P}_{3}$ & 0,529 & 0,2656 & Valid \\
\hline & $\mathrm{P}_{4}$ & 0,696 & 0,2656 & Valid \\
\hline & $\mathrm{P}_{5}$ & 0,646 & 0,2656 & Valid \\
\hline & P 6 & 0,549 & 0,2656 & Valid \\
\hline & $\mathrm{Q}_{7}$ & .385 & 0,2656 & Valid \\
\hline & P 8 & 0,673 & 0,2656 & Valid \\
\hline
\end{tabular}

Sumber: SPSS 2019 data diolah

Berdasarkan tabel 4.1 di atas semua variabel independen dan dependen memiliki nilai $r$ hitung diatas dari $r$ tabel 0 , 2656. Karena itu, semua pernyataan dalam penelitian ini valid. Pengujian reliabilitas dilakukan untuk menentukan tingkat stabilitas dan konsistensi alat ukur. Dalam penelitian ini, uji reliabilitas yang digunakan dalam Cronbach Alpha rumus untuk menentukan hasil pengukuran yang diperoleh untuk memenuhi keandalan kriteria. Instrumen Dika n handal jika memiliki koefisien alpha lebih besar dari 0,600. Berikutini adalah tabel hasil uji reliabilitas: 
Tabel 4.2

Hasil Uji Reliabilitas Data

\begin{tabular}{|l|l|l|l|l|}
\hline No & Kuesioner Variabel & Cronbach's Alpha & r tabel & Keterangan \\
\hline $\mathbf{1}$ & Pengalaman Kerja & 0,624 & $>0,60$ & Reliabel \\
\hline $\mathbf{2}$ & Motivasi & 0,797 & $>0,60$ & Reliabel \\
\hline $\mathbf{3}$ & Kualitas kerja Karyawan & 0,735 & $>0,60$ & Reliabel \\
\hline
\end{tabular}

Sumber: SPSS 2019 data diolah

Dari tabel 4.2 di atas, dapat dilihat bahwa setiap nilai variabal lebih besar dari 0,6. Sehingga semua variabel dinyatakan reliabel.

Tes asumsi klasik, salah satu syarat untuk dapat menggunakan regresi berganda adalah pemenuhan asumsi klasik untuk mendapatkan nilai pemeriksa yang tidak bisa dan efisien dari persamaan regresi berganda. Dalam uji asumsi klasik dalam penelitian ini digunakan 3 buah alat tes, yaitu: 1) Uji normalitas bertujuan untuk apakah dalam model regresi variabel dependen adalah variabel independen yang memiliki distribusi normal atau tidak. Cara yang dapat diambil untuk menguji normalitas adalah dengan menggunakan grafik P-Plot Normal dengan melihat distribusi data. Jika grafik distribusi data mengikuti pola garis diagonal, maka distribusi data normal.

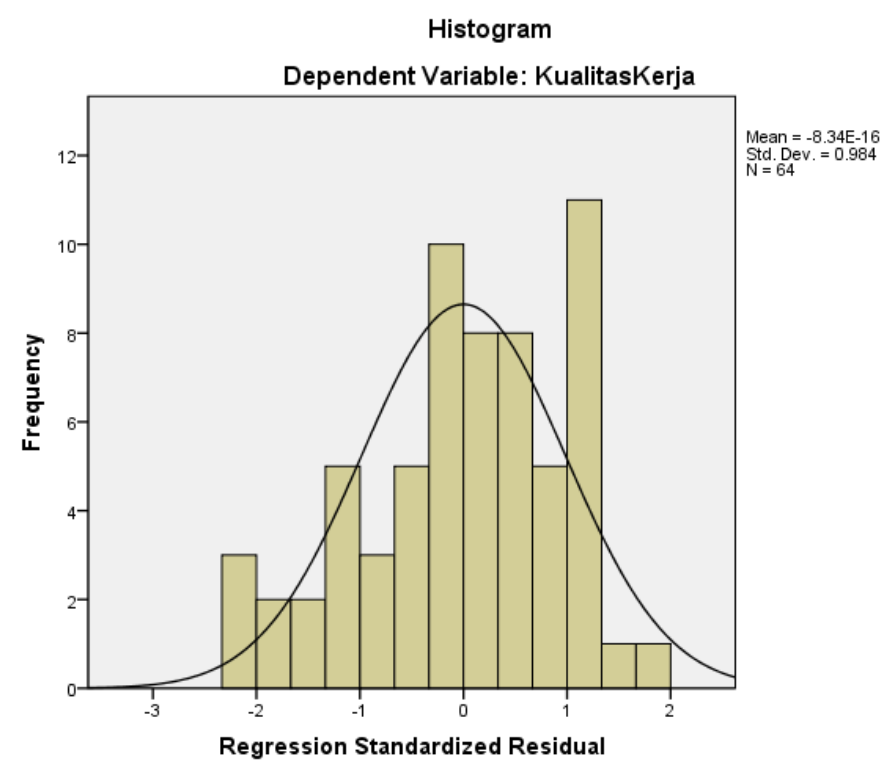

Sumber: SPSS 2019 pemrosesan data

Gambar 4.1 . Grafik Histogram 


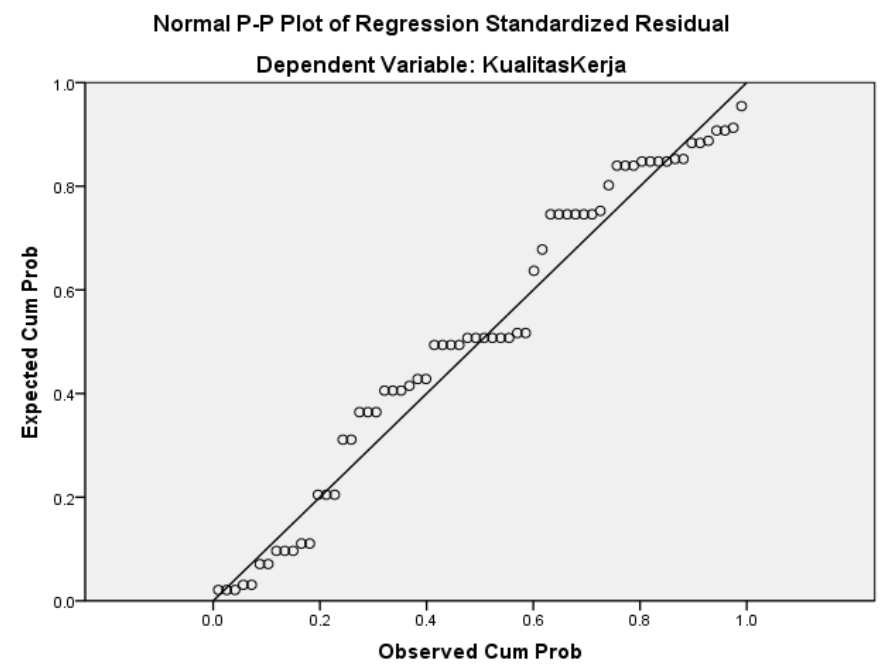

Sumber: SPSS 2019 data diolah

Gambar 4.2 . Kurva P-Plot

Pada Gambar 4.1, histogram normal menunjukkan penyebaran data dalam bentuk lonceng dan tidak menyimpang ke kiri atau ke kanan mengikuti pola distribusi data yang normal . Pada Gambar 4.2 pada grafik P-Plot normal kita dapat melihat titik-titik yang mengikuti data sepanjang garis diagonal. Ini menunjukkan bahwa residu peneliti adalah normal.

Uji Multikolinieritas

Tabel 4.3

Hasil Uji Multikolonieritas

\begin{tabular}{|l|l|l|}
\hline \multirow{2}{*}{ Variabel } & \multicolumn{2}{|l|}{ Collinearity Statistics } \\
\cline { 2 - 3 } & Tolerance & VIF \\
\hline Pengalaman Kerja $\left(\mathrm{X}_{1}\right)$ & 0.326 & 3.068 \\
\hline Motivasi $\left(\mathrm{X}_{2}\right)$ & 0.326 & 3.068 \\
\hline
\end{tabular}

Sumber: SPSS 2019 data diolah

Berdasarkan tabel 4.3 , dapat disimpulkan bahwa beberapa informasi tentang uji multikolinieritas dari penelitian ini, yaitu: 1) Dalam variabel Pengalaman Kerja, nilai toleransi di bawah angka 1 yaitu 0,326 dan nilai VIF di bawah angka 10 adalah 3,068 . sehingga para Pengalaman Kerja variabel bebas dari multikolinearitas; 2) Pada variabel Motivasi, nilai toleransi di bawah angka 1 yaitu 0,326 dan nilai VIF di bawah angka 10 adalah 3,068 . sehingga variabel Motivasi bebas dari multikolinieritas 
Uji hetereterastisitas bertujuan untuk menguji apakah dalam model regresi terjadi ketimpangan varian. Hasil tes hetereterastisitas sebagai berikut:

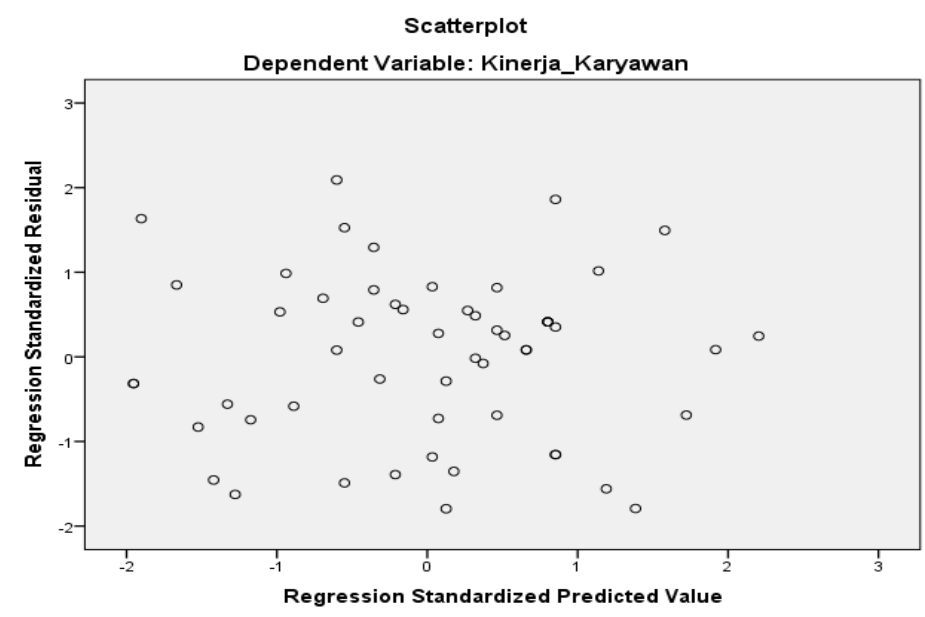

Sumber: SPSS 2019 data diolah

Gambar 4. 3 . Hasil Uji Heterokedastisitas

Berdasarkan grafik scaterplot menunjukkan bahwa tidak ada pola dan titik yang jelas yang menyebar di atas dan di bawah angka 0 pada sumbu Y. Jadi dapat disimpulkan bahwa tidak ada heterokedastisitas dalam model regresi dalam penelitian ini.

Tes Regresi Linier Berganda, dalam pengelolaan data menggunakan regresi linier berganda, dilakukan beberapa langkah untuk menemukan hubungan antara variabel dependen dengan variabel independen, melalui koneksi pengalaman variabel $\left(\mathrm{X}_{1}\right)$, motivasi ( $\left.\mathrm{X}_{2}\right)$ pada kualitas kerja karyawan (Y). Hasil regresi dapat dilihat dari tabel 4. 4:

Tabel 4.4

Hasil Uji Regresi Linear Beganda

Coefficients ${ }^{\mathrm{a}}$

\begin{tabular}{|c|c|c|c|c|c|c|c|}
\hline \multirow[b]{2}{*}{ Model } & \multicolumn{2}{|c|}{$\begin{array}{l}\text { Unstandardized } \\
\text { Coefficients }\end{array}$} & \multirow{2}{*}{\begin{tabular}{|l} 
Standardized \\
Coefficients \\
Beta \\
\end{tabular}} & \multirow[b]{2}{*}{ t } & \multirow[b]{2}{*}{ Sig. } & \multicolumn{2}{|c|}{$\begin{array}{l}\text { Collinearity } \\
\text { Statistics }\end{array}$} \\
\hline & $B$ & Std. Error & & & & Tolerance & VIF \\
\hline (Constant) & 8.786 & 2.807 & & 1.130 & .387 & & \\
\hline Pengalaman_Kerja & .340 & .199 & .264 & 3.714 & .000 & .326 & 3.068 \\
\hline Motivasi & .463 & .132 & .541 & 3.511 & .001 & .326 & 3.068 \\
\hline
\end{tabular}

a. Dependent Variable: Kualitas kerja_Karyawan

Sumber: SPSS 2019 data diolah

Variabel dependen adalah Kualitas Kerja Karyawan (Y) sebesar 8.786, sedangkan variabel independen adalah Pengalaman Kerja $\left(X_{1}\right)$ sebesar 0,340, Motivasi $\left(X_{2}\right)$ 
sebesar 0,463. Sehingga persamaan regresi linier berganda dalam penelitian ini dapat berupa:

$\mathrm{Y}=8.786+0.340 \mathrm{X}_{1}+0.463 \mathrm{X}_{2}+2.807$

Penjelasan dari persamaan regresi linier berganda di atas adalah:

Konstanta (a) $=8.786$

Berdasarkan hasil analisis regresi linier berganda di atas, bahwa nilai kualitas kerja karyawan adalah 8.786 jika variabel lain seperti pengalaman kerja dan motivasi dianggap konstan.

Koefisien $\mathrm{X}_{1}=0,340$

Menunjukkan bahwa hubungan antara pengalaman kerja dan kualitas kerja karyawan adalah 0,340. Jika ada peningkatan satu unit (1\%) dalam pengalaman kerja variabel maka kualitas variabel pekerjaan karyawan akan meningkat sebesar 34 , 0 \%. Merupakan faktor terkecil dalam penelitian ini,

Koefisien $\mathrm{X}_{2}=0,463$

Menunjukkan bahwa hubungan antara motivasi dan kualitas kerja karyawan adalah 0,463. Jika ada peningkatan satu unit (1\%) dalam variabel motivasi, maka kualitas variabel pekerjaan karyawan akan meningkat sebesar 46,3\%. koordinasi adalah variabel yang paling berpengaruh.

\section{Pengujian Hipotesis}

1, Uji Parsial (uji-t)

Uji parsial digunakan untuk mengetahui pengaruh variabel independen secara individual terhadap variabel dependen. Asumsi dalam uji parsial adalah:

1). Jika nilai signifikan $<0,05$, ada pengaruh parsial signifikan pada masing-masing variabel.

2). Jika nilai signifikan $>0,05$, maka tidak ada pengaruh signifikan secara parsial pada masing-masing variabel.

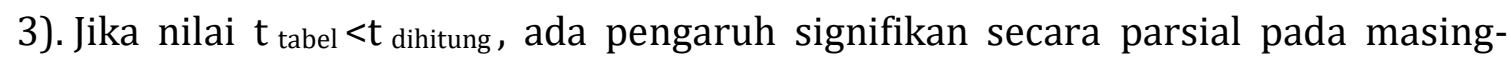
masing variabel.

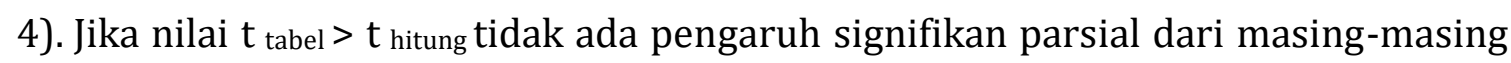
variabel. 
Nilai $t_{\text {tabel }}$ dalam jumlah sampel (n) adalah 55 responden dan total semua variabel $(\mathrm{k})=3$ variabel, maka $\mathrm{df}=\mathrm{n}-\mathrm{k}=55-3=52$ dengan standard error $5 \%$, adalah sama dengan 1, 67469. Di bawah ini adalah hasil dari uji parsial :

Tabel 4.5

Hasil Uji Parsial

Coefficients $^{\mathrm{a}}$

\begin{tabular}{|c|c|c|c|c|c|c|c|}
\hline \multirow[b]{2}{*}{ Model } & \multicolumn{2}{|c|}{$\begin{array}{l}\text { Unstandardized } \\
\text { Coefficients }\end{array}$} & \multirow{2}{*}{\begin{tabular}{|l} 
Standardized \\
Coefficients \\
Beta
\end{tabular}} & \multirow[b]{2}{*}{$\mathrm{t}$} & \multirow[b]{2}{*}{ Sig. } & \multicolumn{2}{|c|}{ Collinearity Statistics } \\
\hline & B & Std. Error & & & & Tolerance & VIF \\
\hline 1 (Constant) & 8.786 & 2.807 & & 1.130 & .387 & & \\
\hline Pengalaman_Kerja & .340 & .199 & .264 & 3.714 & .000 & .326 & 3.068 \\
\hline Motivasi & .463 & .132 & .541 & 3.511 & .001 & .326 & 3.068 \\
\hline
\end{tabular}

a. Dependent Variable: Kualitas kerja_Karyawan

Sumber: SPSS 2019 data diolah

Berdasarkan tabel di atas diketahui bahwa pengaruh variabel independen terhadap variabel dependen berupa:

Pengalaman Kerja memiliki nilai signifikan 0,000 kurang dari 0,05 dan $t$ hitung 3,714 lebih besar dari $t$ tabel 1,67469 . Jadi pengalaman kerja secara parsial berpengaruh positif dan signifikan terhadap kualitas kerja karyawan .

Motivasi memiliki nilai signifikan 0,001 lebih kecil dari 0,05 dan $\mathrm{t}$ hitung 3,511 lebih besar dari $t_{\text {tabel }} 1,67469$. Sehingga motivasi secara parsial berpengaruh positif dan signifikan terhadap kualitas kerja karyawan .

\section{Uji Simultan (Uji F)}

Uji F bertujuan untuk menentukan apakah variabel independen bersama-sama memiliki pengaruh terhadap variabel dependen. Asumsinya adalah:

1. Jika nilai signifikan $<0,05$, maka variabel independen bersama-sama mempengaruhi variabel dependen.

2. Jika nilai signifikan> 0,05, maka variabel independen bersama-sama tidak berpengaruh terhadap variabel dependen.

3. Jika nilai $\mathrm{F}_{\text {tabel }}>\mathrm{F}_{\text {hitung }}$ maka ada pengaruh yang signifikan secara simultan antar variabel.

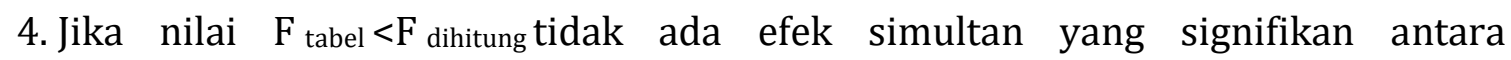
variabel. 
Nilai $\mathrm{F}_{\text {tabel }}$ pada jumlah total variabel (K) 3 (tiga), jumlah sampel (n) dari 55 orang dan tingkat kesalahan 5\%, sebesar 3,18. Hasil Uji Simultan dapat dilihat pada tabel di bawah ini:

Tabel 4.6

Hasil Uji Simultan

\begin{tabular}{|ll|l|l|l|l|l|}
\hline Model & & Sum of Squares & df & Mean Square & F & Sig. \\
\hline 1 & Regression & 305.200 & 2 & 152.600 & 38.575 & $.000^{\mathrm{b}}$ \\
Residual & 205.709 & 52 & 3.956 & & \\
Total & 510.909 & 54 & & & \\
\hline
\end{tabular}

a. Dependent Variable: Kualitas kerja_Karyawan

b. Predictors: (Constant), Motivasi, Pengalaman_Kerja

Sumber: SPSS 2019 data diolah

Hasil perhitungan $F$ adalah 38.575 dengan tingkat signifikansi 0,000. Nilai $F$ yang dihitung 38,575 lebih besar dari $\mathrm{F}_{\text {tabel }} 3,18$. Nilai signifikansi 0,001 lebih kecil dari 0,05. Kemudian variabel pengalaman kerja dan motivasi secara simultan mempengaruhi kualitas kerja karyawan.

\section{Uji Koefisien determinasi $\left(\mathrm{R}^{2}\right)$}

Tabel berikut menunjukkan hasil koefisien determinasi dalam penelitian ini:

Tabel 4.7

Hasil Uji Koefisien Determinasi

Model Summary ${ }^{\mathrm{b}}$

\begin{tabular}{|l|l|l|l|l|}
\hline Model & $\mathrm{R}$ & & & \\
\hline & & & R Square & $\begin{array}{l}\text { Std. Error of the } \\
\text { Estimate }\end{array}$ \\
\hline 1 & & & & \\
\hline
\end{tabular}

a. Predictors: (Constant), Motivasi, Pengalaman_Kerja

b. Dependent Variable: Kualitas kerja_Karyawan

Dari tabel 4. 7 , perhatikan bahwa nilai Adjusted R Square dari 0582 (58, 2 \%). Hasil

ini menunjukkan bahwa 58, 2 \% variabel kualitas pekerjaan karyawan dapat dijelaskan oleh variabel motivasi pengalaman kerja. Sedangkan selisih $41,8 \%$ dijelaskan oleh variabel lain yang tidak diteliti dalam penelitian ini. 


\section{Pengaruh pengalaman kerja terhadap kualitas kerja karyawan}

Dari jawaban kuesioner yang diisi oleh responden, di dapatkan hasil bahwa karyawan PT. Latexindo Toba Perkasa Deli Kabupaten Serdang menganggap pengalaman kerja telah membantu menyelesaikan tugas secara efisien dan dengan pengalaman kerja yang dapat menghasilkan kualitas kerja sesuai dengan kriteria yang diberikan oleh perusahaan, yang berarti karyawan menganggap bahwa pengalaman kerja sangat membantu dalam menyelesaikan pekerjaan sehingga untuk menyelesaikan tugas yang diberikan dengan cepat dan tepat waktu. Karyawan di PT. Latexindo Toba Perkasa Deli Kabupaten Serdang memiliki tingkat keahlian dalam melaksanakan tugas kerja yang diberikan oleh atasan dan karyawan memiliki tingkat pengetahuan yang cukup memadai untuk pekerjaan mereka saat ini, sehingga karyawan dapat dikatakan karyawan yang memiliki keterampilan. Karyawan memiliki penguasaan kerja yang baik dan bersifat komprehensif serta dengan penguasaan pekerjaan yang dimiliki oleh karyawan dapat menyelesaikan tugas dengan baik, sehingga target perusahaan dapat tercapai, hasil penelitian yang dilakukan menunjukkan bahwa karyawan di PT. Latexindo Toba Perkasa Deli Kabupaten Serdang memiliki pengalaman kerja yang tinggi yang meningkatkan kualitas kerja karyawan di perusahaan.

\section{Pengaruh Motivasi terhadap Kualitas Pekerjaan Karyawan}

Dari jawaban kuesioner yang diisi oleh responden, variable Motivasi pemberian finansial ekstrinsik (gaji, upah dan tunjangan) antara individu dan program promosi membuat karyawan bekerja lebih keras dan gaji yang diterima mendukung kualitas kerja karyawan, dalam hal ini motivasi dalam bentuk keuangan dan promosi mampu menunjang kualitas kerja karyawan menjadi lebih baik. Dengan menciptakan kondisi kerja yang aman dan memberikan jaminan keamanan kerja . karyawan PT. Latexindo Toba Perkasa, Kabupaten Deli Serdang akan tenang dan tidak cemas dalam menjalankan tugas yang diberikan. Pengawasan yang dilakukan oleh perusahaan membuat karyawan PT. Latexindo Toba Perkasa lebih bertanggung jawab dan meminimalkan kesalahan dalam bekerja, sehingga hampir setiap pekerjaan dilakukan dengan baik. Menberikan pujian dan penghargaan atas prestasi yang diberikan pekerjaan dan pengakuan atas prestasi merupakan alat motivasi yang kuat, yang berarti 
bahwa motivasi dalam bentuk pujian, pengakuan, dan penghargaan membuat karyawan PT. Latexindo Toba Perkasa, lebih berhasil dan menyelesaikan tugasnya dengan baik untuk mendapatkan pengakuan dari perusahaan dan atasan. Hampir setiap pekerjaan dilakukan dengan baik sehingga dapat dikatakan bahwa karyawan kantor PT. Latexindo Toba Perkasa Deli Kabupaten Serdang memiliki rasa tanggung jawab yang besar atas pekerjaan yang diberikan.

\section{SIMPULAN}

Berdasarkan data yang diperoleh dan setelah proses ulang, maka diperoleh hasil penelitian pengaruh pengalaman kerja dan motivasi terhadap kualitas kerja karyawan di kantor PT. Latexindo Toba Perkasa kab Deli Serdang, didapatkan kesimpulan: Pengalaman kerja berpengaruh positif dan signifikan terhadap kualitas kerja karyawan, di mana t hitung adalah 3,714 lebih besar dari t tabel 1,67469 dengan signifikansi 0,000 kurang dari 0,05. Variabel pengalaman kerja memiliki peran penting dalam meningkatkan kualitas kerja karyawan PT. Latexindo Toba Perkasa Kab Deli Serdang. Sehingga H1 yang menyatakan pengalaman kerja memiliki pengaruh positif dan signifikan terhadap kualitas kerja karyawan dapat diterima. Motivasi kerja memiliki efek positif dan signifikan di mana $t$ hitung untuk 3,511 lebih besar dari t tabel 1,67469 dengan signifikansi 0,001 lebih kecil dari 0,05. Variabel motivasi memiliki peran penting dalam meningkatkan kualitas kerja karyawan PT. Latexindo Toba Kab Perkasa Deli Serdang. Jadi H2 yang menyatakan motivasi memiliki pengaruh positif dan signifikan terhadap kualitas kerja karyawan dapat diterima. Tes simultan, di mana $\mathrm{F}$ hitung 38.575 dengan tingkat signifikansi 0,000. Nilai F hitung adalah 38,575 dan tabel F adalah 3,18. Nilai signifikansi 0,001 lebih kecil dari 0,05. Artinya variabel pengalaman kerja dan motivasi secara simultan berpengaruh terhadap kualitas kerja karyawan PT. Latexindo Toba Perkasa Kab Deli Serdang. Sehingga H3 yang menyatakan pengalaman kerja dan motivasi secara simultan memiliki pengaruh positif dan signifikan terhadap kualitas kerja karyawan dapat diterima. 


\section{DAFTAR PUSTAKA}

Awarmayanti. (2011). Membangun dan Mengembangkan Kepemimpinan Serta meningkatkan kualitas kerja untuk mencapai kesuksesan. Bandung; Refika Aditama

Daud, A. Suharyanto, A. Diawati, P. Nguyen, P.T., Shankar, K. (2019) A Quantitative Analysis of Portfolio Governance Management for Product Innovation in Organization Management Systems, Religación. Revista de Ciencias Sociales y Humanidades, 4(19): 413-418

Edy Sutrisno, (2010). Manajemen Sumber Daya Manusia Edisi Pertama, Pencetakan pertama. Jakarta: Kencana

Ferawanti. (2010). Pengaruh Tingkat Pendidikan dan Pengalaman Kerja Mengenai kualitas kerja Pegawai Bagian Perawatan di Rumah Sakit Ortopedi Prof. Dr. R. Soeharso Surakarta. Fakultas Ekonomi, Universitas Muhammadiyah, Surakarta.

Ghozali, I., (2012). Aplikasi Analisis Multivariat dengan Program SPSS. Semarang: Universitas Diponegoro Handoko, T.H. (2009). Manajemen. Yogyakarta: BFFE-Yogyakarta

Hariandja, (2009). M a najamen Sumber Daya Pengadaan Manusia, Pengembangan, Kompensasi, dan Peningkatan Produktivitas Karyawan. Jakarta; PT. Glasindo

Hasibuan, M.S.P, (2011). Manajemen Sumber Daya Manusia. PT Bumi Aksara, Jakarta

Iskandar. (2008) . Penelitian dan Metodologi Sosial (Kuantitatif dan Kualitatif). Jakarta: GP Press

Mangkunegara, A.A.A.P. (2009). Evaluasi kualitas sumber daya kerja Manusia. Bandung: Refika Aditama

Mangkunegara, A.A.A.P. (2009). Manajemen Sumber Daya Manusia Perusahaan, PT. Teens Rosda Works: Bandung.

Manullang. (2004). Manajemen Personalia, Edisi 3 . Yogyakarta: Gadjah Mada Press Universitas

Mhatis, R.L. \& Jackson. J.H. (2006) Manajemen Sumber Daya Manusia (Manajemen Sumber daya manusia ). Terjemahan Dian Angelia. Jakarta: Salemba Empat.

Moeheriono. (2009). Pengukuran kualitaskerja berbasis kompetensi. Jakarta: Ghalia Indonesia

Mutoha Rofiq, Pengaruh Tingkat Pendidikan, Pengalaman Kerja dan Motivasi

Riduwan. (2011). RumusdanDatadalamAplikasi Statistik. Bandung; Alfabeta

Sa'diyah, C. \& Endratno, H. (2013). Pengaruh Pengalaman Kerja, Motivasi Intrinsik dan Kepuasan Kerja Karyawan dengan Kualitas Karyawan PT Pelita Pelita Pelria Perkasa Sokaraja, Jurnal Bisnis dan Manajemen, Vol. 1, No. 1, 2013, hlm. 78

Siahaan, M. Sianturi, H., Efek dari Pengalaman Kerja dan Motivasi Pajak Pegawai Bekerja Terhadap Kualitas Layanan Pajak, Jurnal. Universitas Bhayangkara, Jabodetabek.

Stephen P. Robbins. (2009). Perilaku Organisasi. Jakarta; Salemba Empat

Sugiyono (2012.) Metode Penelitian Kuantitatif dan Kualitatif R\&D. Bandung; Alfabeta

Tentang kualitas pekerjaan karyawan Kantor Pajak Pare Kediri, Tesis. Universitas Nusantara PGRI Kediri

Wowo. (2011). Manajemen Kualitas Kerja . Jakarta; Rajawali Press

Yunita, K.E., Yulianthini, N.Y. Bagia, I.W, (2004). Pengaruh Pengalaman Kerja dan Penempatan Kerja Menuju Kualitas Kerja KaryawanBali Resort and Spa, Jurnal. Universitas Pendidikan Ganesha Singaraja, Indonesia 